University of Nebraska - Lincoln

DigitalCommons@University of Nebraska - Lincoln

Roman L. Hruska U.S. Meat Animal Research

U.S. Department of Agriculture: Agricultural Center

Research Service, Lincoln, Nebraska

8-1-2021

\title{
Influence of estradiol on bovine trophectoderm and uterine gene transcripts around maternal recognition of pregnancy
}

\author{
Emmalee J. Northrop-Albrecht \\ South Dakota State University \\ Jerica J.J. Rich \\ South Dakota State University \\ Robert A. Cushman \\ USDA, Agricultural Research Service, Bob.Cushman@ars.usda.gov \\ Runan Yao \\ South Dakota State University \\ Xijin Ge \\ South Dakota State University
}

See next page for additional authors

Follow this and additional works at: https://digitalcommons.unl.edu/hruskareports

Part of the Beef Science Commons, and the Meat Science Commons

Northrop-Albrecht, Emmalee J.; Rich, Jerica J.J.; Cushman, Robert A.; Yao, Runan; Ge, Xijin; and Perry, George A., "Influence of estradiol on bovine trophectoderm and uterine gene transcripts around maternal recognition of pregnancy" (2021). Roman L. Hruska U.S. Meat Animal Research Center. 538.

https://digitalcommons.unl.edu/hruskareports/538

This Article is brought to you for free and open access by the U.S. Department of Agriculture: Agricultural Research Service, Lincoln, Nebraska at DigitalCommons@University of Nebraska - Lincoln. It has been accepted for inclusion in Roman L. Hruska U.S. Meat Animal Research Center by an authorized administrator of DigitalCommons@University of Nebraska - Lincoln. 


\section{Authors}

Emmalee J. Northrop-Albrecht, Jerica J.J. Rich, Robert A. Cushman, Runan Yao, Xijin Ge, and George A. Perry 


\title{
Influence of estradiol on bovine trophectoderm and uterine gene transcripts around maternal recognition of pregnancy ${ }^{\dagger}$
}

\author{
Emmalee J. Northrop-Albrecht ${ }^{1}$, Jerica J.J. Rich ${ }^{1}$, Robert A. Cushman ${ }^{2}$, \\ Runan $\mathrm{Yao}^{3}$, Xijin $\mathrm{Ge}^{3}$ and George A. Perry ${ }^{1, *}$
}

${ }^{1}$ Department of Animal Science, South Dakota State University, Brookings, SD, USA, ${ }^{2}$ USDA, Agricultural Research Service, Roman L. Hruska US Meat Animal Research Center, Clay Center, NE, USA and ${ }^{3}$ Department of Mathematics and Statistics, South Dakota State University, Brookings, SD, USA

${ }^{*}$ Correspondence: Texas A\&M Agrilife Research and Extension Center, 1710 FM 3053 N, Overton, TX 75684, USA. Tel: (903) 834-6191; Fax: (903) 834-7140; E-mail: George.Perry@ag.tamu.edu

${ }^{\dagger}$ Grant Support: This project was funded in part by HATCH funds to the South Dakota State University Experiment Station.

Received 5 January 2021; Revised 30 March 2021; Accepted 29 April 2021

\begin{abstract}
Embryo survival and pregnancy success is increased among animals that exhibit estrus prior to fixed time-artificial insemination, but there are no differences in conceptus survival to d16. The objective of this study was to determine effects of preovulatory estradiol on uterine transcriptomes, select trophectoderm (TE) transcripts, and uterine luminal fluid proteins. Beef cows/heifers were synchronized, artificially inseminated (d0), and grouped into either high (highE2) or low (lowE2) preovulatory estradiol. Uteri were flushed (d16); conceptuses and endometrial biopsies $(n=29)$ were collected. RNA sequencing was performed on endometrium. Real-time polymerase chain reaction (RT-PCR) was performed on TE $(n=21)$ RNA to measure relative abundance of IFNT, PTGS2, TM4SF1, C3, FGFR2, and GAPDH. Uterine fluid was analyzed using 2D Liquid Chromatography with tandem mass spectrometry-based Isobaric tags for relative and absolute quantitation (iTRAQ) method. RT-PCR data were analyzed using the MIXED procedure in SAS. There were no differences in messenger RNA (mRNA) abundances in TE, but there were 432 differentially expressed genes ( 253 downregulated, 179 upregulated) in highE2/conceptus versus lowE2/conceptus groups. There were also 48 differentially expressed proteins (19 upregulated, 29 downregulated); 6 of these were differentially expressed (FDR $<0.10$ ) at the mRNA level. Similar pathways for mRNA and proteins included: calcium signaling, protein kinase A signaling, and corticotropin-releasing hormone signaling. These differences in uterine function may be preparing the conceptus for improved likelihood of survival after d16 among highE2 animals.
\end{abstract}

\section{Summary sentence}

Preovulatory estradiol did not impact conceptus survival to d16; however, it did influence uterine gene/protein expressions related to adhesion, endometrial remodeling, metabolism, and immune regulation, which may explain improved pregnancy success.

Key words: maternal recognition of pregnancy, preovulatory estradiol, proteomics, transcriptomics. 


\section{Introduction}

An adequate uterine environment is necessary for maternal and conceptus communication. It must provide sufficient nutrients and endocrine conditions for the establishment and maintenance of pregnancy. In cattle, elongating conceptuses are free floating in the uterus until time of attachment (d20). During this time of elongation, conceptuses are relying on the maternal environment and secretions from the uterus for growth, development, and survival. These secretions from uterine epithelium are termed uterine histotroph. It is composed of a complex mixture of enzymes, growth factors, cytokines, lymphokines, hormones, amino acids, proteins, and glucose [1]. These nutrients stimulate the nutrient-sensing signaling pathway to increase translation of messenger RNA (mRNA), which is critical for conceptus development [2]. Cell signaling through this pathway also stimulates cell migration, invasion, and cell growth and proliferation [3].

When Gray et al. [4] placed uterine gland knockout sheep with fertile rams, no pregnancies were identified on $\mathrm{d} 25$ after insemination. Additionally, blastocyst growth into an elongated bovine conceptus has not been able to be duplicated in vitro [5]. These studies demonstrate that endometrial glands and their secretions are necessary for pregnancy establishment and conceptus development.

Advancements in transcriptomic and proteomic technologies have allowed researchers to gain a better understanding of the uterine milieu and biological mechanisms associated with early pregnancy in ruminants. Interferon tau, progesterone, estradiol, prostaglandins, and cortisol have been reported to act as key regulators in the uterus [6]. Specifically, they can influence gene expression and protein abundances within uterine luminal fluid (ULF) that aid in elongation, recognition of pregnancy, implantation, and placentation.

In particular, preovulatory estradiol impacts follicular growth, oocyte maturation, sperm transport, uterine environment, and embryo survival/development [7]. Cows in standing estrus prior to fixed-time artificial insemination (AI) have increased embryo survival and greater pregnancy success than nonestrus animals [8]. Specifically, when ovariectomized beef cows were treated with estradiol (cypionate or benzoate), embryo survival was increased to $\mathrm{d} 29$ of pregnancy compared with cows that had no exposure to estradiol [9]. Furthermore, cows that received exogenous estradiol only lost $35 \%$ of their existing pregnancies, whereas control animals lost $75 \%$ of their existing pregnancies [9]. Our laboratory has determined that there were no differences in conceptus survival to $\mathrm{d} 16$ of pregnancy between highE2 and lowE2 animals based on conceptus recovery rates, apoptosis of trophectoderm (TE) cells, and interferon tau concentrations in ULF [10]. However, there were differences in select glucose transporter mRNA abundances in caruncular and intercaruncular endometrium [10]. Despite there being extensive research regarding the importance of preovulatory estradiol during early pregnancy, little is known about its impact on uterine and TE transcriptomes and proteomes around maternal recognition of pregnancy. The objectives of the current study were to: 1) examine effects of preovulatory estradiol on critical genes and pathways associated with early pregnancy in cattle and 2) examine the impact of preovulatory estradiol on ULF protein abundances. We hypothesize that differences in uterine environment will have a greater impact on pregnancy success than differences in conceptus developmental competence on $\mathrm{d} 16$ of pregnancy in beef cattle.

\section{Materials and methods}

\section{Animals}

All procedures were approved by the South Dakota State University Institutional Animal Care and Use Committee and US Meat Animal Research Center (USMARC) Animal Care and Use Committees in accordance with the Federation of Animal Science Societies (FASS) guidelines for the care and use of agricultural animals in research.

\section{Treatments}

Angus-crossed beef cows/heifers at the South Dakota State University Beef Breeding Unit (Rep 1: $n=30$, Rep 2: $n=40$ ) and the USMARC (Rep 3: $n=20$ ) were synchronized with a CO-Synch protocol: Gonadotropin releasing hormone $(\mathrm{GnRH})$ administered (100 $\mu \mathrm{g}$ as $2 \mathrm{~mL}$ of Factrel i.m.; Pfizer Animal Health, Madison, $\mathrm{NJ}$ ) on d9, followed by PGF2 alpha (PG; $25 \mathrm{mg}$ as $5 \mathrm{~mL}$ of Lutalyse i.m.; Pfizer Animal Health, Madison, NJ) on $\mathrm{d}-2$, and on $\mathrm{d}-0$, cows were administered GnRH $(100 \mu \mathrm{g}$ as $2 \mathrm{~mL}$ of Factrel i.m.; Pfizer Animal Health, Madison, NJ) and artificially inseminated. Estrus was monitored visually from $\mathrm{d} 0$ through $\mathrm{d} 3$ with the aid of EstroTect patches (Western Point, Inc., Apple Valley, MN). Only animals that ovulated following the GnRH injection at fixed-time AI were utilized. Animals were grouped into either highE2 or LowE2 based on preovulatory estradiol concentrations (replicates 1 and 2) and expression of estrus (all replicates). The threshold estradiol concentration that distinguished the two groups was $4.9 \mathrm{pg} / \mathrm{mL}$. Previous research used a similar cutoff when evaluating changes in ovarian function associated with concentrations of estradiol before a GnRH-induced ovulation in beef cows $[10,11]$.

\section{Ultrasonography and detection of estrus}

For replicates 1 and 2, follicular dynamics were assessed by transrectal ultrasonography using an Aloka $500 \mathrm{~V}$ ultrasound with a $7.5 \mathrm{MHz}$ linear probe (Aloka, Wallingford, CT) on $\mathrm{d}-9,0$, and 3 to characterize follicular development and ovulation. All follicles on each ovary $>8 \mathrm{~mm}$ in diameter were recorded. Ovulation was defined as the disappearance of a previously recorded large follicle and confirmed by changes in circulating concentrations of progesterone.

\section{Blood sampling and radioimmunoassays}

For replicates 1 and 2, blood samples were collected by venipuncture of the jugular vein into $10 \mathrm{~mL}$ Vacutainer tubes (Fisher Scientific, Pittsburgh, PA). For the first replicate, blood was collected on $\mathrm{d}-2$, $-1,0$, then every other day through $\mathrm{d} 16$. For the second replicate, blood was collected on $\mathrm{d}-2,-1,0$, then every other day through d15. Blood was centrifuged at $1200 \times \mathrm{g}$ for $30 \mathrm{~min}$ at $4^{\circ} \mathrm{C}$, and plasma was collected and stored at $-20^{\circ} \mathrm{C}$. Radioimmunoassays were performed on plasma samples to determine circulating progesterone concentrations [12]. Intra- and interassay Coefficient of Variation (CV) were $4.9 \%$ and $7.5 \%$ and $6.0 \%$ and $13.2 \%$ for replicates 1 and 2, respectively, and assay sensitivity was $0.4 \mathrm{ng} / \mathrm{mL}$. Plasma concentrations of estradiol were determined within replicate by a single assay [13]. Intra-assay CVs were $5.03 \%$ and $4.76 \%$, for replicates 1 and 2, respectively. Assay sensitivity was $0.5 \mathrm{pg} / \mathrm{mL}$.

\section{Conceptus recovery}

In replicate 1 , uteri were flushed nonsurgically using a modified Foley catheter on $\mathrm{d} 16$. The catheter was inserted into the vagina through the cervix, and into the uterus. Animals were flushed with 
Table 1. Genes, primer sequences, annealing temperatures, and product sizes for endometrium genes amplified during RT-PCR.

\begin{tabular}{|c|c|c|c|c|c|}
\hline Gene & Primer & Primer sequence & $\begin{array}{l}\mathrm{T}_{\mathrm{a}} \\
\left({ }^{\circ} \mathrm{C}\right)\end{array}$ & Product Size (bp) & References \\
\hline DDX58 & $\begin{array}{l}\text { Forward } \\
\text { Reverse }\end{array}$ & $\begin{array}{l}\text { 5'-GGAAGACCCTGGACCCTACCT-3' } \\
\text { 5'-TATACTGCACCTCTTCСТCССТАAA-3' }\end{array}$ & 60 & 72 & Song et al., 2011 [52] \\
\hline ISG15 & $\begin{array}{l}\text { Forward } \\
\text { Reverse }\end{array}$ & $\begin{array}{l}\text { 5'-GGTATCCGAGCTGAAGCAGTT-3' } \\
\text { 5'-ACCTCCCTGCTGTCAAGGT-3' }\end{array}$ & 60 & 293 & Green et al., 2010 [53] \\
\hline OXTR & $\begin{array}{l}\text { Forward } \\
\text { Reverse }\end{array}$ & $\begin{array}{l}\text { 5'-ACGGTGTCTTCGACTGCTG-3' } \\
\text { 5'-GGTGGCAAGGACGATGAC-3' }\end{array}$ & 60 & 110 & Bauersachs et al., 2006 [18] \\
\hline PARP12 & $\begin{array}{l}\text { Forward } \\
\text { Reverse }\end{array}$ & $\begin{array}{l}\text { 5'-CAACGTGAGCGTGCTGAAAA-3' } \\
\text { 5'-AAGAGCAAGGGGTCGTTCTG-3' }\end{array}$ & 60 & 90 & Primer-Blast \\
\hline RSAD2 & $\begin{array}{l}\text { Forward } \\
\text { Reverse }\end{array}$ & $\begin{array}{l}\text { 5'-GTGGTTCCAGAAGTACGGTGA-3' } \\
\text { 5'-CTTCTTTCCTTGACCACGGC-3' }\end{array}$ & 60 & 103 & Boruszewska et al., 2017 [54] \\
\hline XAF1 & $\begin{array}{l}\text { Forward } \\
\text { Reverse }\end{array}$ & $\begin{array}{l}\text { 5'-GAGGAGGCTCTGAGCTTGC-3' } \\
\text { 5'-GCAGAGAAAGATGTCCGTCC-3' }\end{array}$ & 64 & 143 & Groebner et al., 2010 [55] \\
\hline PRSS8 & $\begin{array}{l}\text { Forward } \\
\text { Reverse }\end{array}$ & $\begin{array}{l}\text { 5'-ATGGGATAGGAGCCGTTGTG-3' } \\
\text { 5'- CTGATCGGACACGAGAGAGC-3' }\end{array}$ & 60 & 161 & Primer-Blast \\
\hline CXCL10 & $\begin{array}{l}\text { Forward } \\
\text { Reverse }\end{array}$ & $\begin{array}{l}\text { 5'-CACTCСТCAАCTCTTCAGGC-3' } \\
\text { 5'-CСАТTCСТTTTCATTGTGGC-3' }\end{array}$ & 50 & 262 & Imakawa et al., 2006 [56] \\
\hline IDO1 & $\begin{array}{l}\text { Forward } \\
\text { Reverse }\end{array}$ & $\begin{array}{l}\text { 5'-GGGCCCATGACTTATGAGAA-3' } \\
\text { 5'-GAGGCAGCTGCTATTTCCAC-3' }\end{array}$ & 60 & 107 & Groebner et al., 2011 [57] \\
\hline MUC13 & $\begin{array}{l}\text { Forward } \\
\text { Reverse }\end{array}$ & $\begin{array}{l}\text { 5'-ACGGGCTGGTGAGACCAAAACC-3' } \\
\text { 5'-GCAGTCAGCTGTCCCGTTGC-3' }\end{array}$ & 60 & 116 & Forde et al., 2013 [35] \\
\hline CLDN4 & $\begin{array}{l}\text { Forward } \\
\text { Reverse }\end{array}$ & 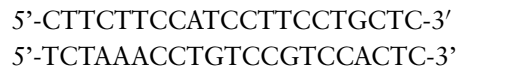 & 64 & 164 & Riedmaier et al., 2014 [58] \\
\hline$F A B P 3$ & $\begin{array}{l}\text { Forward } \\
\text { Reverse }\end{array}$ & $\begin{array}{l}\text { 5'-GAGATCAGCTTCAAGCTGGGA-3' } \\
\text { 5'-CTTGTCCATTCCACTTCTGCAC-3' }\end{array}$ & 60 & 121 & Mansouri-Attia et al., 2009 [19] \\
\hline GAPDH & $\begin{array}{l}\text { Forward } \\
\text { Reverse }\end{array}$ & $\begin{array}{l}\text { 5'-GATTGTCAGCAATGCCTCCT-3' } \\
\text { 5'-GGTCATAAGTCCCTCCACGA-3' }\end{array}$ & 60 & 94 & Han et al., 2006 [59] \\
\hline
\end{tabular}

Table 2. Genes, primer sequences, annealing temperatures, and product sizes for TE genes amplified during RT-PCR.

\begin{tabular}{|c|c|c|c|c|c|}
\hline Gene & Primer & Primer Sequence & $\mathrm{T}_{\mathrm{a}}\left({ }^{\circ} \mathrm{C}\right)$ & Product size (bp) & References \\
\hline \multirow[t]{2}{*}{ IFNT } & Forward & 5'- GCTATCTCTGTGCTCCATGAGATG-3' & 58 & 359 & Shorten et al., 2018 [60] \\
\hline & Reverse & 5'-AGTGAGTTCAGATCTCCACCCATC-3' & & & \\
\hline \multirow[t]{2}{*}{ PTGS2 } & Forward & 5'-GCATTCTTTGCCCAGCACTTCACCC-3' & 58 & 418 & Lussier et al., 2017 [61] \\
\hline & Reverse & 5'-CTATCAGGATTAGCCTGCTTGTCTGG-3' & & & \\
\hline \multirow[t]{2}{*}{ TM4SF1 } & Forward & 5'- TCTTCTCCGGTATCCTGGGA-3' & 56 & 155 & Primer3 \\
\hline & Reverse & 5'- TCCAATGAGTGCAGCCAGTA-3' & & & \\
\hline \multirow[t]{2}{*}{ C3 } & Forward & 5'AGAACATCTGGGTCAAGGGG-3' & 56 & 201 & Primer3 \\
\hline & Reverse & 5'-ATCATGTTCTGCTCCССАCA-3' & & & \\
\hline \multirow[t]{2}{*}{ FGFR2 } & Forward & 5'-CACCACGGACAAAGAAATTG-3' & 58 & 113 & Akbarinejad et al., 2016 [62] \\
\hline & Reverse & 5'-ATGCAGAGTGAAAGGATATCCC-3' & & & \\
\hline \multirow[t]{2}{*}{ GAPDH } & Forward & 5'-GATTGTCAGCAATGCCTCCT-3' & 60 & 94 & Han et al., 2006 [59] \\
\hline & Reverse & 5'-GGTCATAAGTCCCTCCACGA-3' & & & \\
\hline
\end{tabular}

$100 \mathrm{~mL}$ of flush media to maintain a constant volume. Uteri were massaged, and fluid drained through a filter above a conical tube. Flush media was assessed under a microscope at $10 \times$ to determine whether a conceptus was present or not. If no conceptus was recovered, additional flush media was added, and this additional media was collected separately. TE (highE2: $n=6$, lowE2: $n=3$ ) was separated from embryo proper, snap froze and was then stored at $-80^{\circ} \mathrm{C}$.

In replicate 2, reproductive tracts were collected from the abattoir immediately following slaughter on $\mathrm{d} 16$ and kept on ice. An incision was made at the anterior end of the uterine horn contralateral to the corpus luteum; a plastic tube was placed in the uterine tip and sutured to prevent any fluid loss while the other horn was clamped off. Uterine horns were flushed with $30 \mathrm{~mL}$ of flush media and then massaged for equal fluid distribution in the uterus. Uterine flush fluid was then collected in a $50-\mathrm{mL}$ conical tube and examined under a microscope at $10 \times$ to determine if a conceptus was present. TE (highE2: $n=6$, lowE2: $n=3$ ) was separated from embryo proper, was snap frozen, and was then stored at $-80^{\circ} \mathrm{C}$.

In replicate 3, reproductive tracts were collected from the abattoir at USMARC immediately following slaughter on d16. An incision was made at the anterior end of the uterine horn contralateral to the corpus luteum; a plastic tube was placed in the uterine tip and sutured to prevent any fluid loss while the other horn was clamped off. Uterine horns were flushed with $20 \mathrm{~mL}$ of flush media and then 
massaged for equal fluid distribution in the uterus. Uterine flush fluid was then collected in a 50-mL conical tube and examined under a microscope at $10 \times$ to determine if a conceptus was present. TE (highE2: $n=8$, lowE2: $n=2$ ) was separated from embryo proper and was then stored at $-80^{\circ} \mathrm{C}$.

\section{Endometrium collection, RNA extraction, and RNA sequencing}

In replicate 1, endometrium from midway down the ipsilateral uterine horn was collected via a Jackson Uterine Biopsy instrument (Universal Surgical Instruments and Better Surgical Instrumentation; $n=23$ ). We were unable to pass the biopsy tool on some heifers in the study. In replicate $2(n=28)$ and replicate $3(n=20)$, the ipsilateral uterine horn was cut anterior to the bifurcation, and endometrial tissue was collected midway down the ipsilateral horn.

For all replicates, total cellular RNA was extracted using the Qiagen RNeasy Plus Mini Kit (Austin, TX) following the manufacturer's instructions. Pure RNA was dissolved in nuclease free water, and a spectrophotometer (NanoDrop Technologies, Wilmington, DE) was used to determine RNA concentration for each sample. RNA integrity was then determined using an Agilent RNA Screen Tape System. Only RNA samples (lowE2/noconceptus: $n=8$, lowE2/conceptus: $n=3$, highE2/noconceptus: $n=7$, highE2/ conceptus: $n=11$ ) with a RNA integrity number (RIN) $>7$ were sent to the University of Minnesota Genomic Center for total RNA sequencing. They created 29 dual-indexed TruSeq-stranded mRNA libraries. All libraries were combined into a single pool and were sequenced across two lanes of a NovaSeq S2, $2 \times 50$-bp run. There were approximately $24 \mathrm{M}$ reads generated for each sample. Illumina Basis QC analysis was performed on all paired-end sequences. All libraries had mean quality scores that were $\geq 30$, and the pools were gel sized selected to have inserts that were approximately 200 base pairs long.

\section{Endometrium RT-PCR validation}

Twelve differentially expressed genes (DEGs) according to sequencing were selected for validation using real-time polymerase chain reaction (RT-PCR); additional animals were added to the validation population. Total cellular RNA $(n=55$; lowE2/noconceptus: $n=17$ lowE2/conceptus: $n=6$, highE2/noconceptus: $n=15$, highE2/conceptus: $n=17$ ) was diluted to $70 \mathrm{ng} / \mu \mathrm{L}$ ( $280 \mathrm{ng} /$ reaction), and RT-PCR was performed in duplicate using iScript One-Step RT-PCR Kit with SYBR Green (BioRad) and Stratagene MX 3000P QPCR machine. Expression of DDX58, ISG15, OXTR, PARP12, RSAD2, XAF1, PRSS8, CXCL10, IDO1, MUC13, CLDN4, and $F A B P 3$ was measured using the primers in Table 1 , and GAPDH was used as a reference gene. All primers were diluted to a concentration of $10 \mu \mathrm{M}$. Each plate contained negative controls to assure no background contamination. The PCR program was $10 \mathrm{~min}$ at $50^{\circ} \mathrm{C}$ and $1 \mathrm{~min}$ at $95^{\circ} \mathrm{C}$ for inactivation of reverse transcriptase. Transcription was then followed by $15 \mathrm{~s}$ at $95^{\circ} \mathrm{C}$ for melting and $30 \mathrm{~s}$ at the designated annealing temperature (Table 1) for 40 cycles. All CVs were less than $20 \%$. Amplicons were electrophoresed on $2 \%$ agarose gels to determine product size and were verified for identity by sequencing (Iowa State Genomics Core).

\section{TE RNA extraction and RT-PCR}

Total cellular RNA was extracted using the Qiagen RNeasy Mini Kit (Austin, TX), following the manufacturer's instructions with some modifications. TE tissue (Rep 1: $n=7$, Rep 2: $n=5$, Rep 3: $n=9$ )

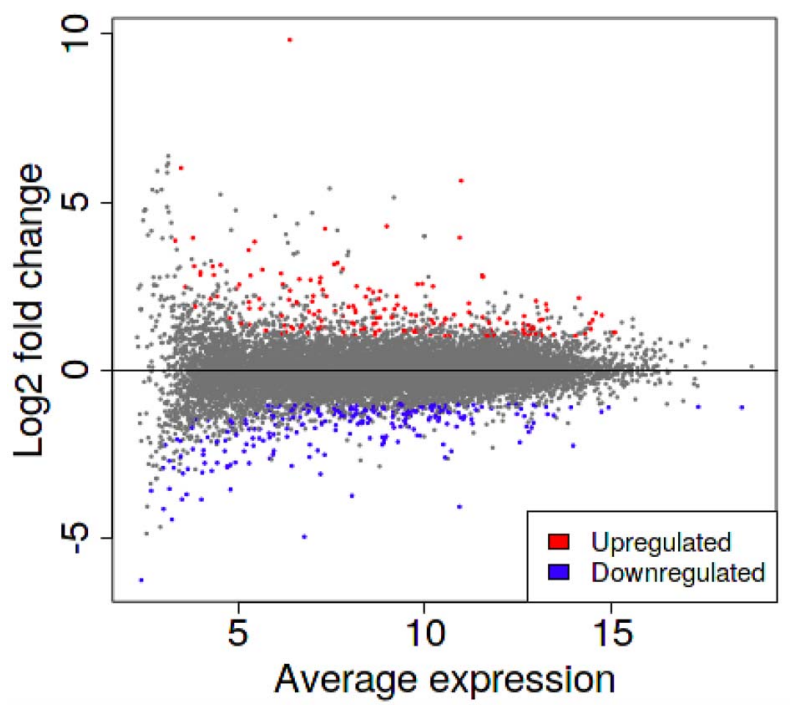

Figure 1. MA plot depicting DEGs among the highE2/conceptus versus lowE2/conceptus comparison.

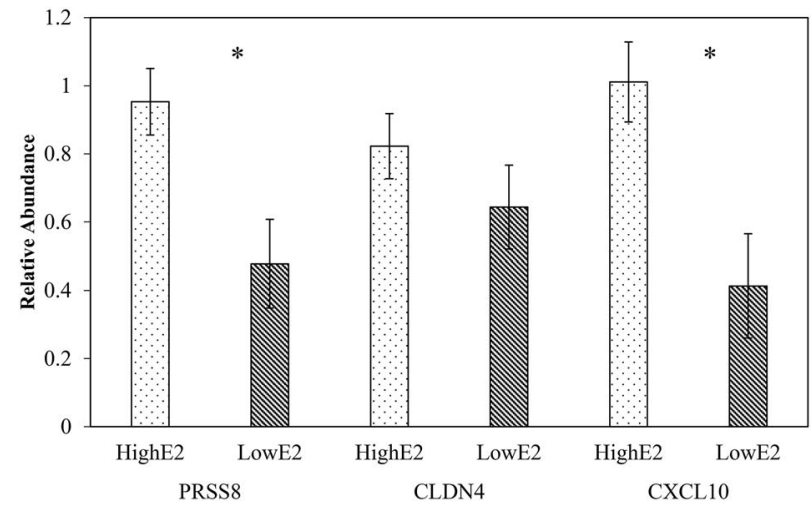

Figure 2. Endometrium mRNA abundances for PRSS8, CLDN4, and CXCL10 on day 16 among highE2 and lowE2 animals. HighE2 animals had increased PRSS8 $(P=0.005)$ and $C X C L 10(P=0.003)$ transcript abundances compared with lowE2 animals; CLDN4 expression was not different $(* P<0.05)$.

was lysed in RLT buffer using a 22-gauge needle and vortexed. After the first RW1 wash solution step, $80 \mu \mathrm{L}$ of DNase solution was added directly to the membrane and incubated for $15 \mathrm{~min}$ at room temperature. Pure RNA was dissolved in nuclease-free water, and a spectrophotometer was used to determine RNA concentration for each sample. The RNA samples were stored at $-80^{\circ} \mathrm{C}$. The RNA $(190 \mathrm{ng})$ was reverse transcribed into cDNA via the BioRad iScript cDNA synthesis kit following the manufacturer's instructions. RTPCR was then performed on TE cDNA (6 ng) in duplicate using BioRad iTaq Universal SYBER Green Supermix and BioRad C1000 Touch CFX96 Real Time System.

Expression of IFNT, PTGS2, TM4SF1, C3, and FGFR2 was measured using the primers in Table 2 and GAPDH used as a reference gene. All primers were diluted to a concentration of $10 \mu \mathrm{M}$. Each plate had negative controls to assure no background contamination. The PCR program was $5 \mathrm{~min}$ at $95^{\circ} \mathrm{C}$ for melting, $15 \mathrm{~s}$ at the given annealing temperature (Table 2) and $15 \mathrm{~s}$ at $70^{\circ} \mathrm{C}$ for extension, for 40 cycles. All CVs were less than $20 \%$. Amplicons were electrophoresed and were verified for identity by sequencing (Iowa State Genomics Core). 
Table 3. DEGs in the endometrium of highE2 versus lowE2 animals with a conceptus.

\begin{tabular}{|c|c|c|c|c|}
\hline Biological function & Gene abbreviation & Gene name & Log2Fold change & FDR \\
\hline \multirow[t]{12}{*}{ Endometrial remodeling } & MYLK & Myosin light chain kinase & -1.17 & 2.03E-07 \\
\hline & $A D A M 12$ & ADAM metallopeptidase domain 12 & -1.67 & 0.00377 \\
\hline & TAGLN & Transgelin & -2.13 & 0.00207 \\
\hline & ACTA2 & Actin, alpha 2, smooth muscle & -1.83 & 0.00604 \\
\hline & MYL9 & Myosin light chain 9 & -1.02 & 0.00597 \\
\hline & COL1A2 & Collagen type I alpha 2 chain & -1.08 & 0.00666 \\
\hline & COL3A1 & Collagen type III alpha 1 chain & -1.10 & 0.00976 \\
\hline & PRSS8 & Protease, serine 8 & 2.06 & 0.00756 \\
\hline & $G R N$ & Granulin precursor & 1.13 & 0.000946 \\
\hline & $H S P E$ & Heparanase & -2.62 & 0.02 \\
\hline & ADAMTS15 & $\begin{array}{l}\text { ADAM metallopeptidase, thrombospondin type } 1 \\
\text { motif } 15\end{array}$ & -1.39 & 0.0236 \\
\hline & $L G M N$ & Legumain & 1.40 & 0.0291 \\
\hline \multirow[t]{12}{*}{ Metabolic } & FABP3 & Fatty acid binding protein 3 & 2.82 & 0.00604 \\
\hline & SLC2A1 & Solute carrier family 2 member 1 & 1.64 & 0.0357 \\
\hline & SLC5A5 & Solute carrier family 5 member 5 & 3.13 & 0.00606 \\
\hline & SLC27A5 & Solute carrier family 27 member 5 & 1.40 & 0.00013 \\
\hline & $L P L$ & Lipoprotein lipase & -2.57 & 0.00509 \\
\hline & SLC38A4 & Solute carrier family 38 member 4 & -1.18 & 0.0217 \\
\hline & FAAH & Fatty acid amide hydrolase & -2.93 & 0.0233 \\
\hline & $A M P D 3$ & Adenosine monophosphate deaminase 3 & 1.80 & 0.03 \\
\hline & FBP1 & Fructose-bisphosphatase 1 & 3.19 & 0.0312 \\
\hline & ACO2 & Aconitase 2 & 1.23 & 0.0327 \\
\hline & SLC27A2 & Solute carrier family 27 member 2 & 1.82 & 0.049 \\
\hline & SLC7A2 & Solute carrier family 7 member 2 & -1.06 & 0.049 \\
\hline \multirow[t]{8}{*}{ Adhesion } & CLDN4 & Claudin 4 & 1.71 & 0.0494 \\
\hline & F5 & Coagulation factor $\mathrm{V}$ & 1.34 & 0.0147 \\
\hline & MUC13 & Mucin 13 , cell surface associated & 1.53 & 0.0276 \\
\hline & ITGA3 & Integrin subunit alpha 3 & 1.21 & 0.0173 \\
\hline & $\mathrm{CDH} 4$ & Cadherin 4 & -1.74 & 0.0186 \\
\hline & CLEC4F & C-type lectin domain family 4 member $\mathrm{F}$ & 2.36 & 0.0208 \\
\hline & TROAP & Trophinin associated protein & -1.44 & 0.0217 \\
\hline & ITGB5 & Integrin subunit beta 5 & 1.49 & 0.0265 \\
\hline \multirow[t]{13}{*}{ Immune regulation } & IDO1 & Indoleamine 2,3-dioxygenase 1 & 2.50 & 0.0182 \\
\hline & $B P I$ & Bactericidal/permeability-increasing protein & 1.48 & 0.0386 \\
\hline & $B O L A-N C 1$ & Nonclassical MHC class I antigen & 1.03 & 0.00234 \\
\hline & $\mathrm{C} 2$ & Complement C2 & 1.51 & 0.0488 \\
\hline & $C F B$ & Complement factor B & 2.20 & 0.00001 \\
\hline & CR2 & Complement C3d receptor 2 & -2.39 & 0.00795 \\
\hline & $C 1 Q L 2$ & Complement C1q like 2 & 4.21 & 0.00005 \\
\hline & OAS2 & 2'-5'-oligoadenylate synthetase 2 & 1.58 & 0.0437 \\
\hline & $S 100 A 12$ & S100 calcium binding protein A12 & 1.66 & 0.0213 \\
\hline & CD48 & CD48 molecule & 1.27 & 0.00055 \\
\hline & MIC1 & Major histocompatibility class I related protein & 1.82 & 0.00352 \\
\hline & CXCL10 & $\mathrm{C}-\mathrm{X}-\mathrm{C}$ motif chemokine ligand 10 & 2.78 & 0.00133 \\
\hline & CXCL11 & $\mathrm{C}-\mathrm{X}-\mathrm{C}$ motif chemokine ligand 11 & 1.93 & 0.0208 \\
\hline
\end{tabular}

\section{Mass spectrometry}

There were 28 samples of ULF that were used to make a total of eight pools that were sent to the Mass Spectrometry Facility at the University of Minnesota. There were two independent pools made for each of the following groups: lowE2/noconceptus, lowE2/conceptus, highE2/noconceptus, and highE2/conceptus. Each animal was represented equally within the appropriate pool. Protein quantification was conducted using a 2D Liquid Chromatography with tandem mass spectrometry (LC MS/MS)-based 8plex Isobaric tags for relative and absolute quantitation (iTRAQ) quantitative method. Samples were pooled, reduced, alkylated by methyl methanethiosulfonate digested with trypsin, and labeled with iTRAQ reagents. Scaffold Q+ (version Scaffold_4.8.4, Proteome Software Inc., Portland, OR) was used to quantitate label-based quantitation (iTRAQ) peptide and protein identifications.

\section{Data analyses}

For RNA sequencing, quality reads were mapped to the bovine reference genome ARS-UCD1.2 using kallisto [14]. Genes were filtered at a cutoff of 0.5 counts per million before fitting data into a negative binomial distribution. Differential expression analysis was conducted using the bioconductor package, DESeq2. Genes 


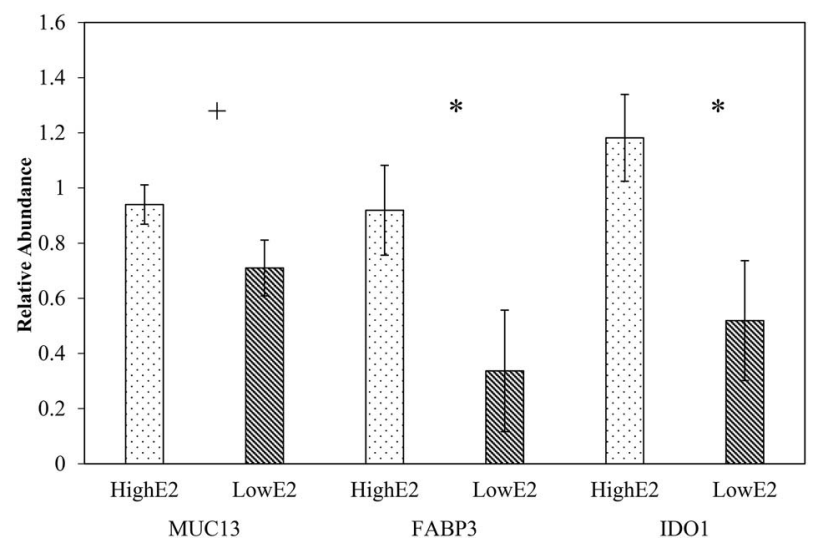

Figure 3. Endometrium mRNA abundances for MUC13, FABP3, and IDO1 on day 16 among highE2 and lowE2 animals. HighE2 animals had increased FABP3 $(P=0.04)$ and IDO1 $(P=0.02)$ transcript abundances compared with lowE2 animals. There was a tendency for highE2 animals to have increased MUC13 $(P=0.07)$ transcript abundance in the endometrium on day $16 \mathrm{com}$ pared with lowE2 animals $\left({ }^{*} P>0.05,+P<0.10\right)$.

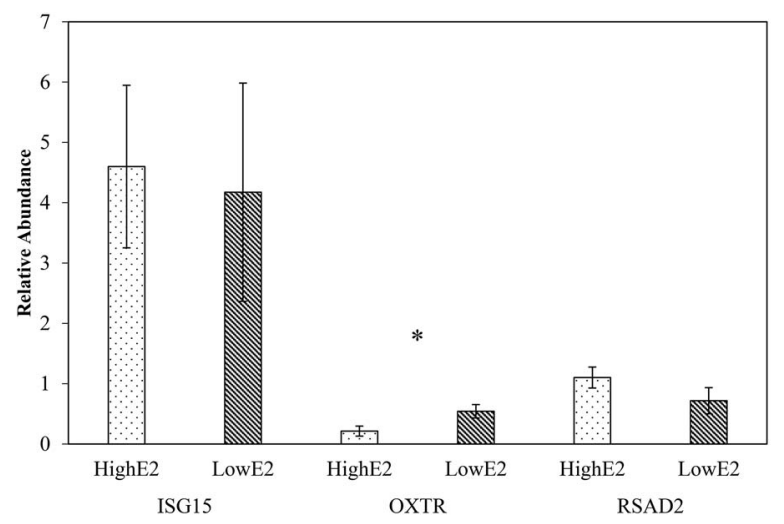

Figure 4. Endometrium mRNA abundances for ISG15, OXTR, and RSAD2 on day 16 among highE2 and lowE2 animals. HighE2 animals had decreased OXTR $(P=0.02)$ transcript abundance compared with lowE2 animals. There was no difference in ISG15 and RSAD2 transcript abundances in the endometrium on day $16(* P<0.05)$.

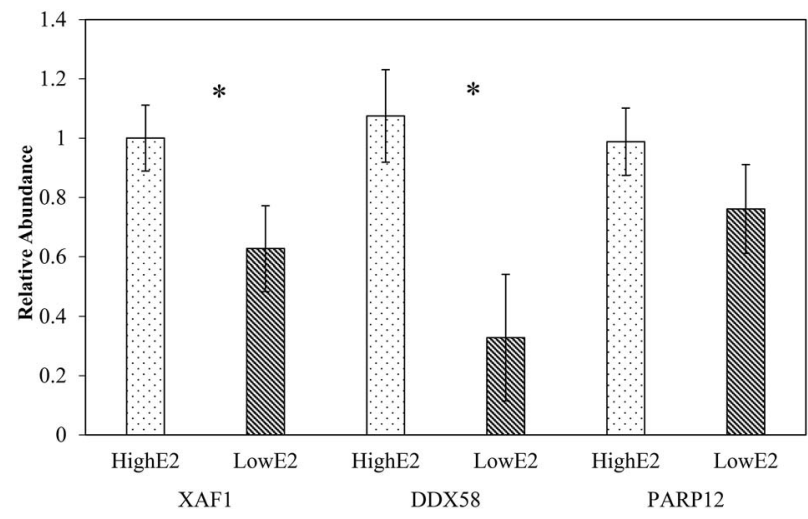

Figure 5. Endometrium mRNA abundances for XAF1, DDX58, and PARP12 on day 16 among highE2 and lowE2 animals. HighE2 animals had increased XAF1 $(P=0.02)$ and DDX58 $(P=0.0007)$ transcript abundances compared with lowE2 animals. There was no difference in PARP12 transcript abundances in the endometrium on day $16\left({ }^{*} P>0.05\right)$.

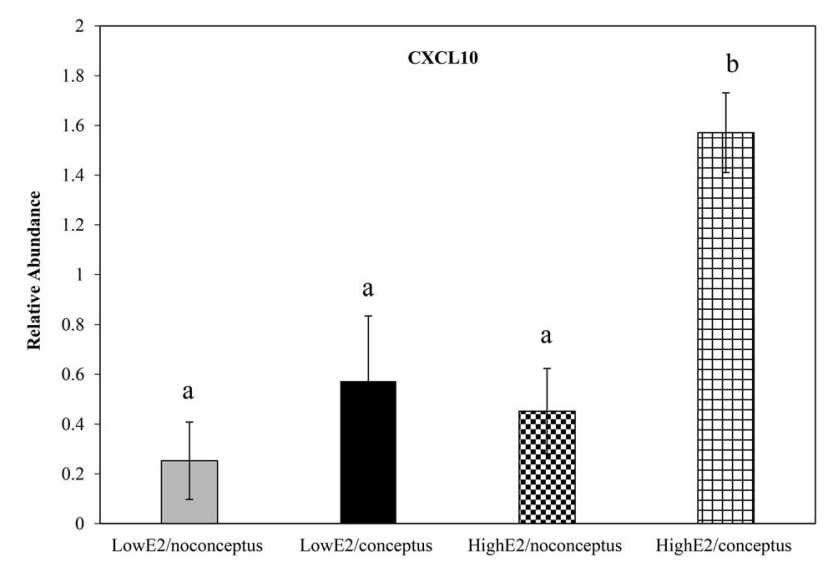

Figure 6. Preovulatory estradiol exposure and conceptus presence interaction $\left({ }^{\mathrm{ab}} P=0.04\right)$ on $C X C L 10$ mRNA abundance in endometrium on day 16 of pregnancy.

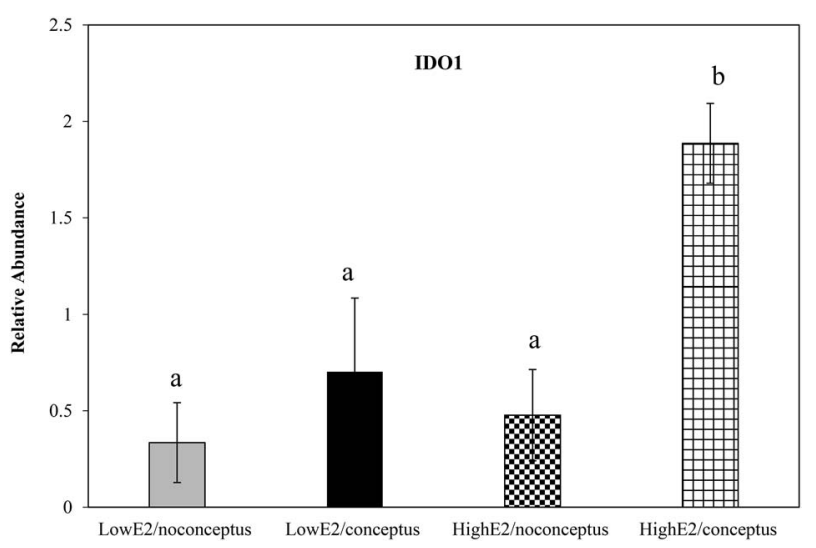

Figure 7. Preovulatory estradiol exposure and conceptus presence interaction $\left({ }^{\mathrm{ab}} P=0.06\right)$ on IDO1 mRNA abundance in endometrium on day 16 of pregnancy.

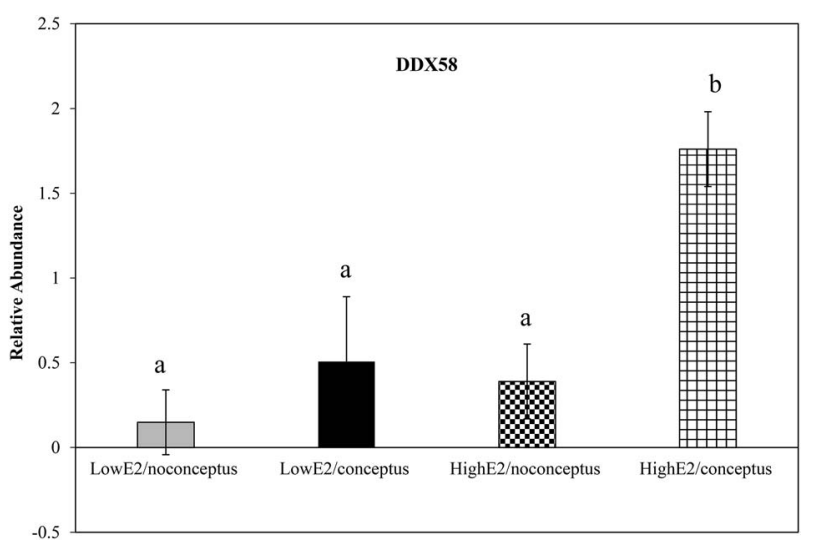

Figure 8. Preovulatory estradiol exposure and conceptus presence interaction $\left({ }^{\mathrm{ab}} P=0.06\right)$ on DDX58 mRNA abundance in endometrium on day 16 of pregnancy.

were considered differentially expressed if false discovery rate $($ FDR $)<0.05$ and fold change was $>2$. TE data were analyzed using the MIXED procedure in SAS with GAPDH being used as a reference gene. Endometrium RT-PCR data were analyzed using the MIXED procedure in SAS with conceptus presence, preovulatory estradiol 
Table 4. DEPs downregulated in highE2/conceptus animals compared with lowE2/conceptus animals.

\begin{tabular}{|c|c|c|c|}
\hline Abbreviation & Protein name & Log2Fold change & FDR \\
\hline UTMP & Uterine milk protein & -2.02 & 0.00027 \\
\hline ORM1 & Alpha-1-acid glycoprotein & -1.31 & $<0.0001$ \\
\hline ANXA8 & Annexin A8 & -1.23 & $<0.0001$ \\
\hline ANXA1 & Annexin A1 & -0.89 & $<0.0001$ \\
\hline$F G G$ & Fibrinogen gamma-B chain & -0.88 & 0.00031 \\
\hline$F G B$ & Fibrinogen beta chain & -0.86 & $<0.0001$ \\
\hline$A P L P 2$ & Amyloid beta precursor like protein 2 & -0.73 & 0.001 \\
\hline SLC25A5 & ADP/ATP translocase 2 & -0.71 & $<0.0001$ \\
\hline PHB2 & Prohibitin & -0.7 & $<0.0001$ \\
\hline COX4I1 & $\begin{array}{l}\text { Cytochrome c oxidase subunit } 4 \text { isoform } 1 \text {, } \\
\text { mitochondrial }\end{array}$ & -0.68 & 0.001 \\
\hline PHB & Prohibitin-2 & -0.67 & $<0.0001$ \\
\hline ANXA2 & Annexin A2 & -0.65 & $<0.0001$ \\
\hline FGA & Fibrinogen alpha chain & -0.65 & $<0.0001$ \\
\hline HIST1H2AC & Histone $\mathrm{H} 2 \mathrm{~A}$ & -0.64 & 0.001 \\
\hline ANXA4 & Annexin A4 & -0.61 & 0.00039 \\
\hline ANXA3 & Annexin A3 & -0.59 & 0.00016 \\
\hline RPN1 & $\begin{array}{l}\text { Dolichyl-diphosphooligosaccharide-protein } \\
\text { glycosyltransferase subunit } 1\end{array}$ & -0.59 & 0.00051 \\
\hline HIST1H4 & Histone $\mathrm{H} 4$ & -0.55 & 0.001 \\
\hline$I M M T$ & MICOS complex subunit MIC60 & -0.54 & 0.00015 \\
\hline ANXA11 & Isoform 2 of Annexin A11 & -0.53 & 0.001 \\
\hline$H 2 A F Y$ & Core histone macro-H2A & -0.53 & $<0.0001$ \\
\hline C3 & Complement C3 & -0.49 & $<0.0001$ \\
\hline RAP1B & Ras-related protein Rap- $1 \mathrm{~b}$ & -0.47 & 0.001 \\
\hline APOA1 & Apolipoprotein A-I & -0.46 & 0.001 \\
\hline HIST1H1E & Histone cluster $1 \mathrm{H} 1$ family member e & -0.42 & 0.0001 \\
\hline$E Z R$ & Ezrin & -0.42 & $<0.0001$ \\
\hline$A 2 M$ & Alpha-2-macroglobulin & -0.36 & 0.001 \\
\hline ANPEP & Aminopeptidase $\mathrm{N}$ & -0.27 & $<0.0001$ \\
\hline
\end{tabular}

exposure, and their interaction included in the model. For mass spectrometry, peptide identifications were accepted if they could be established at greater than $95.0 \%$ probability by the Scaffold Local FDR algorithm. Protein identifications were accepted if they could be established at greater than $99.0 \%$ probability and contained at least two identified peptides. Protein probabilities were assigned by the Protein Prophet algorithm. Proteins that contained similar peptides and could not be differentiated based on MS/MS analysis alone were grouped to satisfy the principles of parsimony. Normalization was performed iteratively (across samples and spectra) on intensities, as described in [15]. Medians were used for averaging. Spectra were $\log$ transformed, pruned of those matched to multiple proteins, and weighted by adaptive intensity weighting logarithm. The FDR was adjusted using Benjamini-Hochberg procedure $(P<0.05)$ to identify significance based on permutation tests.

\section{Pathway analysis}

Identification of enriched pathways was conducted using Ingenuity Pathway Analysis (IPA; Qiagen) software. A list of DEGs or differentially expressed proteins (DEPs) was uploaded to the IPA tool. IPA functional analysis tools identified biological functions and/or pathways that were most significant to the data set $(P<0.05)$ according to a righted tailed Fisher exact test. IPA currently supports only human, mouse, and rat species with full content, so the bovine species is supported at the ortholog level; therefore some significant genes and proteins may not be included in the analysis. Emphasis was given to top canonical pathways and molecular and cellular functions.

\section{Results}

\section{Endometrium gene expression}

There were 17,765 genes identified in the current study. The results and discussion focus on differentially expressed genes (DEGs) based on preovulatory estradiol exposure (highE2 versus lowE2 animals), and the interaction between preovulatory estradiol exposure and conceptus presence (highE2/conceptus versus lowE2/conceptus).

Preovulatory estradiol exposure (bighE2 versus lowE2). There were 1,111 DEGs between the highE2 and lowE2 groups. Specifically, there were 619 genes that were downregulated (KRT1, VGF, OXTR, CLDN10, NPY) and 492 genes that were upregulated (IDO1, CXCL10, AQP8, KRT17, OAS2) in the highE2 group. Top canonical pathways associated with these DEGs included: interferon signaling (2.32E-07), activation of interferon regulatory factors by cytosolic pattern recognition receptors (8.39E-06), hepatic fibrosis/hepatic stellate cell activation (7.31E-05), retinoic acid-mediated apoptosis signaling (1.88E-04), and agranulocyte adhesion and diapedesis (9.52E-04). The main molecular and cellular functions associated with DEGs were: cell cycle (182 molecules; 2.20E-05-5.65E-17), cellular movement (224 molecules; 3.23E-05-4.23E-15), cellular development (204 molecules; 2.18E-05-3.57E-13), cellular growth and 
Table 5. DEPs upregulated in highE2/conceptus animals compared with lowE2/conceptus animals.

\begin{tabular}{|c|c|c|c|}
\hline Abbreviation & Protein name & Log2Fold change & FDR \\
\hline PLEC & Plectin & 0.2 & $<0.0001$ \\
\hline AТР 5B & ATP synthase subunit beta, mitochondrial & 0.25 & 0.001 \\
\hline HSPD1 & $60 \mathrm{kDa}$ heat shock protein, mitochondrial & 0.26 & 0.00068 \\
\hline IDH2 & $\begin{array}{l}\text { Isocitrate dehydrogenase [NADP], } \\
\text { mitochondrial }\end{array}$ & 0.26 & 0.001 \\
\hline CNDP2 & Cytosolic nonspecific dipeptidase & 0.29 & 0.00039 \\
\hline ALDH18A1 & Delta-1-pyrroline-5-carboxylate synthase & 0.3 & 0.001 \\
\hline HNRNPK & Heterogeneous nuclear ribonucleoprotein $\mathrm{K}$ & 0.32 & 0.001 \\
\hline ACTN4 & Alpha-actinin-4 & 0.32 & $<0.0001$ \\
\hline IDH1 & Isocitrate dehydrogenase [NADP] & 0.33 & 0.00061 \\
\hline$P R K A R 2 A$ & $\begin{array}{l}\text { cAMP-dependent protein kinase type II-alpha } \\
\text { regulatory subunit }\end{array}$ & 0.37 & 0.00042 \\
\hline SPTBN1 & Spectrin beta chain & 0.38 & $<0.0001$ \\
\hline GPD1L & $\begin{array}{l}\text { Glycerol-3-phosphate dehydrogenase } \\
{[\mathrm{NAD}(+)]}\end{array}$ & 0.39 & 0.001 \\
\hline$A L D H 2$ & Aldehyde dehydrogenase, mitochondrial & 0.4 & 0.00049 \\
\hline$H S D 17 B 4$ & Hydroxysteroid (17-beta) dehydrogenase 4 & 0.4 & $<0.0001$ \\
\hline GPLD1 & $\begin{array}{l}\text { Phosphatidylinositol-glycan-specific } \\
\text { phospholipase D }\end{array}$ & 0.56 & $<0.0001$ \\
\hline ACAA1 & Acetyl-CoA acyltransferase 1 & 0.58 & 0.00067 \\
\hline TST & Thiosulfate sulfurtransferase & 0.58 & $<0.0001$ \\
\hline GSTM4 & Glutathione S-transferase Mu 1 & 0.66 & 0.001 \\
\hline GOT1 & Aspartate aminotransferase, cytoplasmic & 1.02 & $<0.0001$ \\
\hline
\end{tabular}

proliferation (237 molecules; 2.75E-05-3.57E-13), and cell death and survival (273 molecules; 2.59E-05-4.03E-13).

Preovulatory estradiol and conceptus presence interaction. There were 432 DEGs between the highE2/conceptus and the lowE2/conceptus groups. Specifically, there were 253 genes that were downregulated (UTMP, C3, MYL9, ADAM12, and LPL) in the highE2/conceptus (Figure 1). There were 179 genes that were upregulated (PRSS8, MUC13, IDO1 CXCL10, CXCL11, and FBP1) in the highE2/conceptus group compared with the lowE2/conceptus group (Figure 1). Table 3 emphasizes the importance of select DEGs in various biological processes. Top canonical pathways associated with these DEGs included: calcium signaling (7.73E$05)$, caveolar-mediated endocytosis signaling (1.00E-04), agranulocyte adhesion and diapedesis (1.77E-04), and axonal guidance signaling (2.37E-04). The main molecular and cellular functions associated with the DEGs were: cellular movement (97 molecules; 2.21E-03-9.63E-08), molecular transport (81 molecules; 1.87E-03$2.68 \mathrm{E}-07)$, cellular growth and proliferation (79 molecules; $2.02 \mathrm{E}-$ 03-4.80E-07), cellular assembly and organization (74 molecules; $1.45 \mathrm{E}-03-1.24 \mathrm{E}-05)$, and cell death and survival (124 molecules; $2.22 \mathrm{E}-03-2.18 \mathrm{E}-05)$.

RT-PCR endometrium validation. In endometrium, highE2 animals had increased mRNA abundances of PRSS8 $(P=0.005$; Figure 2$)$, CXCL10 ( $P=0.003$; Figure 2), IDO1 $(P=0.02$; Figure 3), FABP3 $(P=0.04$; Figure 3$), X A F 1 \quad(P=0.05$; Figure 5$)$, and DDX58 $(P=0.007$; Figure 5$)$ on $\mathrm{d} 16$. HighE2 animals had decreased OXTR mRNA abundance $(P=0.02$; Figure 4$)$ in the endometrium compared with lowE2 animals. HighE2 animals also had a tendency to have increased mRNA abundance of MUC13 $(P=0.07$; Figure 3) compared with animals with low preovulatory estradiol concentrations. There was no difference in CLDN4 $(P=0.26$; Figure 2), RSAD2 ( $P=0.17$; Figure 4$), I S G 15$ ( $P=0.85$; Figure 4$)$, and PARP12 $(P=0.23$; Figure 5$)$ mRNA abundance in the endometrium among highE2 and lowE2 animals. There was a conceptus and preovulatory exposure interaction for CXCL10 $(P=0.04$; Figure 6$)$ and a tendency for an interaction for IDO1 $(P=0.06$; Figure 7$)$ and DDX58 $(P=0.06$; Figure 8$)$.

\section{TE gene expression}

There were no differences in mRNA abundances for IFNT, PTGS2, TM4SF1, C3, and FGFR2 in the TE collected from highE2 and lowE2 animals on $\mathrm{d} 16$ of pregnancy $(P>0.22)$.

\section{Uterine protein expression}

Proteins in ULF were identified and quantified using mass spectrometry. This approach detected 6989 peptides and 1269 proteins in the pools of ULF. The results and discussion focus on differentially expressed proteins based on preovulatory estradiol exposure (highE2 versus lowE2) among animals that had a conceptus recovered from their reproductive tract (highE2/conceptus versus lowE2/ conceptus).

HighE2/conceptus versus lowE2/conceptus. There were 48 DEPs between the highE2/conceptus and the lowE2/conceptus groups. Specifically, there were 29 proteins that were downregulated (UTMP, ORM1, ANXA8, ANXA1, and FGG; Table 4) and 19 proteins that were upregulated (GOT1, GSTM4, TST, ACAA1, and GPLD1) in the highE2/conceptus group compared with the lowE2/conceptus group (Table 5). Top canonical pathways associated with these DEPs included: acute phase response signaling (3.17E-05), aryl hydrocarbon receptor signaling (5.06E-04), coagulation system (6.39E-04), and PPAR signaling (9.87E-04). The main molecular and cellular functions associated with the DEPs were carbohydrate metabolism (four molecules; 3.99E-02-1.10E-06), nucleic acid metabolism (eight molecules; 4.60E-02-3.29E-06), small molecule biochemistry 
(14 molecules; 4.60E-02-3.29E-06), cellular development (4.01E02-9.92E-05), and cellular function and maintenance (12 molecules; 4.91E-02-9.92E-05).

\section{Discussion}

Transcription in the endometrium is mainly regulated by complex interactions of estradiol and progesterone. These hormones act as transcription factors by binding to nuclear receptors causing conformational changes, ultimately allowing receptors to bind to chromatin and cause transcriptional changes within hours [16, 17]. Previous researchers have focused on differences in transcriptomes [18-22] and proteomes [21, 23-26] during various time points in the preimplantation phase of development in ruminants. However, prior to the current study there was little known about the impact of preovulatory estradiol on uterine and TE transcripts around the critical period of maternal recognition of pregnancy.

There has been extensive research regarding the impact of preovulatory estradiol on the uterine environment and embryo survival in cattle. On d6, heifers that exhibited estrus yielded embryos that were more advanced in stage and had improved quality when compared with heifers that did not exhibit estrus; however, recovery rates were not different [11]. Bridges et al. [27] concluded that there was no difference in conceptus size and interferon tau concentrations on d15.5 based on preovulatory estradiol exposure. On d16, Northrop et al. [10] determined that there were no differences in conceptus survival based on apoptosis in the TE, IFNT, protein, and glucose concentrations in ULF among highE2 and lowE2 animals. On day 19, Davoodi and colleagues reported that genes associated with maternal immune system, attachment between the endometrium and conceptus, and Corpus Luteum (CL) maintenance were favorably expressed in cows that exhibited estrus near the time of AI compared with cows that did not. Additionally, they reported that cows that exhibited estrus yielded longer conceptuses [28]. The following discussion focuses on biological processes associated with the DEGs and DEPs among highE2 and lowE2 animals on $\mathrm{d} 16$ of pregnancy in cattle.

Forde et al. [24] previously analyzed protein content in ULF from cyclic and pregnant heifers on $\mathrm{d} 16$. They further analyzed proteins specifically produced by day 16 conceptuses in culture media. Thirty proteins were identified to be unique to ULF from pregnant heifers and produced by short-term in vitro cultured conceptuses on $\mathrm{d} 16$ [24]. In the current study, 28 of these proteins were identified on d16 in ULF. There were 20 proteins that were upregulated, and 8 proteins that were downregulated in the highE2/conceptus group compared with the lowE2/conceptus group. They concluded that these proteins could possibly be involved in facilitating interactions between the conceptus and endometrium during pregnancy recognition. If this is true, these proteins may contribute to the improved pregnancy rates observed in cows that display estrus during a timed AI protocol $[9,29]$.

\section{Endometrial remodeling}

Remodeling of the endometrium and chorionic extracellular matrix (ECM) is critical for successful implantation and placentation. Specifically, remodeling of the ECM supports proliferation, differentiation, migration of binucleate cells, and attachment [30]. Other studies in ruminants have reported genes involved in this process being expressed during gestation [17,31]. RNA sequencing revealed that MYLK, ADAM12, TAGLN, ACTA2, MYL9, COL1A2,
COL3A1, HSPE, and ADAMTS15 were downregulated genes, whereas PRSS8, LGMN, and GRN were upregulated in the endometrium of highE2 animals with a conceptus compared with lowE2 animals with a conceptus. Specifically, PRSS 8 is a serine protease that is reported to play a role in endometrial epithelial morphology establishment, tissue remodeling, and trophoblast invasion during early pregnancy in the rhesus monkey [32]. Additionally, PRSS8 knockout mice exhibited lethality due to placental insufficiency [33]. The validation of PRSS 8 by RTPCR suggests that these remodeling pathways are contributing to increased pregnancy success in cows that exhibit behavioral estrus.

\section{Adhesion}

Adhesion molecules play a critical role in the attachment process between fetal chorionic binucleate cells and luminal epithelium. In the current study, RNA sequencing revealed that CLDN4, F5, MUC13, ITGA3, CLEC4F, ITGB5 genes were upregulated, whereas $\mathrm{CDH} 4$ and TROAP were downregulated when comparing the highE2/conceptus and lowE2/conceptus groups. Mucins are heavily glycosylated proteins that contain glycans that are recognized by blastocyst [34]. Specifically, MUC13 mRNA was upregulated in pregnant caruncular tissue on d20 of pregnancy in cattle [19]. Additionally, MUC13 mRNA was increased in the endometrium of highly fertile and subfertile heifers compared with infertile heifers on d17 of gestation [22]. Forde et al. [35] reported increased MUC13 expression in the endometrium as pregnancy progressed (d13 to d19). In the current study, RT-PCR validation determined that MUC13 had a tendency to be increased in highE2 endometrium compared with lowE2 endometrium.

In the present study, mass spectrometry also identified that actinin 4 (ACTN4) had increased abundance in ULF among the highE2/conceptus group. Previously, on d16 in sheep, around time of attachment, ACTN4 was elevated in pregnant ULF compared with nonpregnant ULF [23]. The alpha actinin family proteins are involved in growth and remodeling. They can bind to filamentous actin and regulate cytokinesis, cell adhesion, spreading, migration, and signaling [36]. An increase in expression of cell adhesion molecules at the mRNA and protein level among highE2 pregnant animals suggests that the endometrium is undergoing changes in order to prepare for attachment prior to $\mathrm{d} 19$, which may increase the likelihood of survival to $\mathrm{d} 29$ among these animals.

\section{Immune}

The developing conceptus is made up of both maternal and paternal genes. The innate and adaptive immune system must be appropriately regulated to prevent rejection of the conceptus during pregnancy, as it is considered foreign by the female body. For RNA sequencing, the following genes associated with immune response were increased when comparing highE2/conceptus versus lowE2/conceptus: IDO1, BPI, BOLA-NC1, C2, CFB, C1QL2, OAS2, S100A12, CD48, MIC1, CXCL10, and CXCL11. RT-PCR results with additional animals added further confirmed sequencing data that there was an effect of preovulatory estradiol, conceptus presence, and an interaction on IDO1 and CXCL1O transcript abundance in the endometrium on $\mathrm{d} 16$ in the present study. Indoleamine 2, 3-dioxygenase (IDO1) catalyzes the rate-limiting step in tryptophan catabolism. Previous research determined that placental cells express IDO, which causes tryptophan depletion leading to suppression of T-cell proliferation at the maternal-fetal interface [37]. In pregnant mice, treatment with an IDO inhibitor 
resulted in inhibition of tryptophan catabolism, which initiated maternal lymphocytes to facilitate fetal rejection [37].

Chemokines are multifunctional molecules that recruit immune cells to inflammatory regions [38]. Specifically, there is abundant chemokine expression at the maternal-fetal interface. In humans, leukocytes are infiltrated to the implantation site, and they are responsible for maintaining an appropriate balance between embryo protection and accepting hemiallogenic tissues [39]. Specifically, on $\mathrm{d} 17$ there was more than an 11-fold increase in CXCL10 expression in the uterus of pregnant cows [40]. CXCL10 mRNA expression was also downregulated in subfertile dairy cows compared with fertile cows on d17 of pregnancy [41]. On d19, CXCL10 mRNA expression in the uterus was favorably expressed on $\mathrm{d} 19$ of gestation among cows that exhibited estrus around the time of AI compared with animals that did not [28].

Additionally, mass spectrometry revealed increased HSP 60 protein abundance among highE2/conceptus animals compared with lowE2/conceptus animals, whereas uterine milk protein (UTMP) and complement 3 protein $(C 3)$ had decreased protein abundance in the highE2/conceptus group. Specifically, the complement component system functions in both embryonic and host protection [42]. Furthermore, an intact complement system during early pregnancy at the placental interface optimizes placental development and function [43]. In humans, previous research has established that excessive or misdirected complement activation can lead to pregnancy complications such as pregnancy loss, fetal growth restriction, and preterm birth [43]. Therefore, the uterus and/or conceptus in highE2 animals may be downregulating the abundance of this protein to avoid pregnancy loss. Together these data confirm the importance of uterine immune function in recognition of pregnancy and suggest that function of this pathway differs between females with increased circulating E2 concentrations at estrus compared with females with decreased circulating E2 concentrations at estrus.

\section{Metabolic}

An increase in metabolites during pregnancy is necessary to ensure adequate nutrients for growth, development, and survival of the conceptus. The following genes associated with metabolic function were upregulated: FABP3, SLC2A1, SLC5A5, SLC27A2, SLC27A5, $A M P D 3, F B P 1$, and ACO2, whereas $L P L, S L C 7 A 2$, SLC38A4, and $F A A H$ were downregulated when comparing highE2/conceptus and lowE2/conceptus. Mass spectrometry revealed that the following proteins/enzymes associated with metabolic function were upregulated: ACAA1, IDH1, IDH2, GPD1L, and GOT1.

Lipids are essential for structural properties, providing energy for proliferating tissue, cell signaling, and generation of ATP. Endometrium is the main source of lipids, which are especially important during rapid conceptus elongation in ruminants. Fatty acid-binding protein $(F A B P 3)$ is involved in uptake, metabolism, and transport of long chain fatty acids. On d17, FABP 3 mRNA in the endometrium was increased among high-fertility heifers compared with subfertile heifers [22]. It also had increased expression in the caruncular tissue of pregnant animals compared with cyclic animals on d20 of gestation [19]. In the current study, RT-PCR results with additional animals added further confirmed sequencing results that there was an effect of preovulatory estradiol on FABP3 transcript abundance in the endometrium on $\mathrm{d} 16$. However, there was no preovulatory estradiol and conceptus interaction.

Glucose is one of the main energy sources used by conceptuses for growth and development, it is known to regulate trophoblast proliferation and function [44]. Transport of glucose into the uterus is mediated by facilitative and/or sodium-dependent transporters. The SLC2A1 transporter has been localized mainly in the glandular and luminal epithelial cells [45]. This glucose transporter appears to be regulated by both progesterone and interferon tau in the glandular epithelium [46]. Previously, our laboratory reported that highE2 animals had increased SLC2A1 mRNA abundance in intercaruncular and caruncular tissue compared with lowE2 animals on d16 [10].

\section{RNA sequencing and mass spectrometry similarities}

There were six DEPs (ANXA8, APLP2, PHB, ANPEP, ALDH2, $G P L D 1)$ that were also considered differentially expressed $($ FDR $<0.10)$ at the mRNA level. Lack of similarities in mRNA and protein expression may be attributed to: posttranscriptional (alternative splicing, transport, mRNA stability), translational (miRNAs), and posttranslational (phosphorylation, ubiquitination, methylation, and acetylation) regulatory factors. Similar pathways associated with DEGs and proteins among highE2 and lowE2 animals with a conceptus included: calcium signaling, protein kinase A signaling, corticotropin-releasing hormone (CRH) signaling, and LPS/IL-1-mediated inhibition of RXR function. Calcium signaling in humans has been reported to be crucial for implantation and placental development [47]. Additional functions include: second messenger in signal transduction pathways, motility, apoptosis, regulation of mitochondrial function, and cell cycle progression [48]. Protein kinase A signaling functions in regulating metabolism and cell growth/proliferation. $\mathrm{CRH}$ is involved in anti-inflammatory response, stromal cell decidualization in humans [49], and implantation in mice [50]. The LPS/IL-1-mediated inhibition of RXR function pathway ultimately causes release of proinflammatory cytokines (IL-1) leading to a decrease in expression of hepatic genes that leads to impaired metabolic activity [51].

In summary, this study identified differences in critical genes/proteins and pathways among highE2 and lowE2 animals on day 16 of pregnancy. These differences in uterine function, specifically relating to metabolism, immune regulation, endometrial remodeling, and adhesion may be preparing the conceptus for improved likelihood of survival after $\mathrm{d} 16$ among highE2 animals. We hypothesize that these differences in conceptus survival are most likely occurring around the time of attachment; however, further research is needed to determine underlying biological mechanisms that lead to increased conceptus survival among highE2 animals between $\mathrm{d} 16$ and $\mathrm{d} 29$.

\section{Disclosure statement}

Names are necessary to report factually on available data; however, USDA neither guarantees nor warrants the standard of products, and use of names by USDA implies no approval of the product to the exclusion of others that may also be suitable. USDA is an equal opportunity provider and employer.

\section{Author contribution}

E.J.N.: this project was part of her dissertation. She helped design the study, collected the data, analyzed the data, and wrote the manuscript.

J.J.J.R.: helped with the collection of all the data.

R.A.C.: helped with the design of the study, collection of the data, analysis of the data, and writing of the manuscript.

R.Y.: helped with the analysis of the data. 
X.G.: helped with the analysis of the data.

G.A.P.: this study was conducted in his laboratory. He helped with the design of the study, the collection of the data, analysis of the data, and writing of the manuscript.

Conflict of interest: The authors have declared that no conflict of interest exists.

\section{References}

1. Gao H, Wu G, Spencer TE, Johnson GA, Li X, Bazer FW. Select nutrients in the ovine uterine lumen. I. Amino acids, glucose, and ions in uterine lumenal flushings of cyclic and pregnant ewes. Biol Reprod 2009; 80:86-93.

2. Martin PM, Sutherland AE. Exogenous amino acids regulate trophectoderm differentiation in the mouse blastocyst through an mTORdependent pathway. Dev Biol 2001; 240:182-193.

3. Liu L, Chen L, Chung J, Huang S. Rapamycin inhibits F-actin reorganization and phosphorylation of focal adhesion proteins. Oncogene 2008; 27:4998-5010.

4. Gray CA, Taylor KM, Ramsey WS, Hill JR, Bazer FW, Bartol FF, Spencer TE. Endometrial glands are required for preimplantation conceptus elongation and survival. Biol Reprod 2001; 64:1608-1613.

5. Betteridge KJ, Flechon JE. The anatomy and physiology of pre-attachment bovine embryos. Theriogenology 1988; 29:155-187.

6. Brooks K, Burns G, Spencer TE. Conceptus elongation in ruminants: roles of progesterone, prostaglandin, interferon tau and cortisol. J Anim Sci Biotechnol 2014; 5:53.

7. Pohler KG, Geary TW, Atkins JA, Perry GA, Jinks EM, Smith MF. Follicular determinants of pregnancy establishment and maintenance. Cell Tissue Res 2012; 349:649-664.

8. Perry GA, Smith MF, Lucy MC, Green JA, Parks TE, Macneil MD, Roberts AJ, Geary TW. Relationship between follicle size at insemination and pregnancy success. PNAS 2005; 102:5268-5273.

9. Madsen CA, Perry GA, Mogck CL, Daly RF, MacNeil MD, Geary TW. Effects of preovulatory estradiol on embryo survival and pregnancy establishment in beef cows. Anim Reprod Sci 2015; 158:96-103.

10. Northrop EJ, Rich JJJ, Cushman RA, McNeel AK, Soares EM, Brooks K, Spencer TE, Perry GA. Effects of preovulatory estradiol on uterine environment and conceptus survival from fertilization to maternal recognition of pregnancy. Biol Reprod 2018; 99:629-638.

11. Larimore EL, Admundson OL, Bird SL, Funnell BJ, Kruse SG, Bridges GA, Perry GA. Influence of estrus at fixed-time artificial insemination on early embryonic development in beef cattle. J Anim Sci 2015; 93:2806-2812.

12. Engel CL, Patterson HH, Perry GA. Effect of dried corn distillers grains plus solubles compared with soybean hulls, in late gestation heifer diets, on animal and reproductive performance. J Anim Sci 2008; 86:1697-1708.

13. Perry GA, Perry BL. Effects of standing estrus and supplemental estradiol on changes in uterine $\mathrm{pH}$ during a fixed-time artificial insemination protocol. J Anim Sci 2008; 86:2928-2935.

14. Bray NL, Pimentel H, Melsted P, Pachter L. Near-optimal probabilistic RNA-seq quantification. Nat Biotechnol 2016; 34:525.

15. Oberg AL, Mahoney DW, Eckel-Passow JE, Malone CJ, Wolfinger RD, Hill EJ, Cooper LT, Onuma OK, Spiro C, Therneau TM, Bergen RH. Statistical analysis of relative labeled mass spectrometry data from complex samples using ANOVA. J Proteome Res 2008; 7:225-233.

16. Murdoch FE, Gorski J. The role of ligand in estrogen receptor regulation of gene expression. Mol Cell Endocrinol 1991; 78:C103-C108.

17. Stormshak F, Bishop CV. Estrogen and progesterone signaling: genomic and nongenomic actions in domestic ruminants. J Anim Sci 2008; 86:299-315.

18. Bauersachs S, Ulbrich SE, Gross K, Schmidt SE, Meyer HH, Weinigerkind H, Vermehren M, Sinowatz F, Blum H, Wolf E. Embryo-induced transcriptome changes in bovine endometrium reveal species-specific and common molecular markers of uterine receptivity. Reproduction 2006; 132:319-331.
19. Mansouri-Attia N, Aubert J, Reinaud P, Giraud-Delville C, Taghouti G, Galio L, Everts RE, Degrelle S, Richard C, Hue I, Yang X, Tian XC, et al. Gene expression profiles of bovine caruncular and intercaruncular endometrium at implantation. Physiol Genomics 2009; 39:14-27.

20. Mamo S, Mehta JP, McGettigan P, Fair T, Spencer TE, Bazer FW, Lonergan P. RNA sequencing reveals novel gene clusters in bovine conceptuses associated with maternal recognition of pregnancy and implantation. Biol Reprod 2011; 85:1143-1151.

21. Brooks K, Burns GW, Moraes JG, Spencer TE. Analysis of the uterine epithelial and conceptus transcriptome and luminal fluid proteome during the peri-implantation period of pregnancy in sheep. Biol Reprod 2016; 95:88.

22. Moraes JGN, Behura SK, Geary TW, Hansen PJ, Neibergs NL, Spencer TE. Uterine influences on conceptus development in fertility-classified animals. PNAS 2018; 115:E1749-E1758.

23. Koch JM, Ramadoss J, Magness RR. Proteomic profile of uterine luminal fluid from early pregnant ewes. J Proteome Res 2010; 9:3878-3885.

24. Forde N, McGettigan PA, Mehta JP, O’Hara L, Mamo S, Bazer FW, Spencer TE, Lonergan P. Proteomic analysis of uterine fluid during the pre-implantation period of pregnancy in cattle. Reproduction 2014; 147:575-587.

25. Forde N, Bazer FW, Spencer TE, Lonergan P. Conceptualizing' the endometrium: identification of conceptus-derived proteins during early pregnancy in cattle. Biol Reprod 2015; 92:156.

26. Arianmanesh M, Fowler PA, Al-Gubory KH. The sheep conceptus modulates proteome profiles in caruncular endometrium during early pregnancy. Anim Reprod Sci 2016; 175:48-56.

27. Bridges GA, Mussard ML, Pate JL, Ott TL, Hansen TR, Day ML. Impact of preovulatory estradiol concentrations on conceptus development and uterine gene expression. Anim Reprod Sci 2012; 133:16-26.

28. Davoodi S, Cook RF, Fernandes AC, Cappellozza BI, Vasconcelos JL, Cerri RL. Expression of estrus modifies the gene expression profile in reproductive tissues on day 19 of gestation in beef cows. Theriogenology 2016; 85:645-655.

29. Richardson BN, Hill SL, Stevenson JS, Djira GD, Perry GA. Expression of estrus before fixed-time AI affects conception rates and factors that impact expression of estrus and the repeatability of expression of estrus in sequential breeding seasons. Anim Reprod Sci 2016; 166:133-140.

30. Imakawa K, Bai R, Fujiwara H, Ideta A, Aoyagi Y, Kusama K. Continuous model of conceptus implantation to the maternal endometrium. $J$ Endocrinol 2017; 233:R53-R65.

31. Ribeiro ES, Greco LF, Bisinotto RS, Lima FS, Thatcher WW, Santos JE. Biology of preimplantation conceptus at the onset of elongation in dairy cows. Biol Reprod 2016; 94:97.

32. Lin HY, Zhang H, Yang Q, Wang HX, Wang HM, Chai KX, Chen LM, Zhu C. Expression of prostasin and protease nexin-1 in rhesus monkey (Macaca mulatta) endometrium and placenta during early pregnancy. $J$ Histochem Cytochem 2006; 54:1139-1147.

33. Hummler E, Dousse A, Rieder A, Stehle JC, Rubera I, Osterheld MC, Beermann F, Frateschi S, Charles RP. The channel-activating protease CAP1/Prss 8 is required for placental labyrinth maturation. PLoS One 2013; 8(2):e55796. https://doi.org/10.1371/journal.pone.0055796.

34. Aplin JD. Adhesion molecules in implantation. Rev Reprod 1997; 2:84-93.

35. Forde N, Mehta JP, McGettigan PA, Mamo S, Bazer FW, Spencer TE, Lonergan P. Alterations in expression of endometrial genes coding for proteins secreted into the uterine lumen during conceptus elongation in cattle. BMC Genomics 2013; 14:321.

36. Kao HY. The actinin family proteins: biological function and clinical implications. Cell Biosci 2015; 5:48.

37. Munn DH, Zhou M, Attwood JT, Bondarev I, Conway SJ, Marshall B, Brown C, Mellor AL. Prevention of allogeneic fetal rejection by tryptophan catabolism. Science 1998; 281:1191-1193.

38. Red-Horse K, Drake PM, Gunn MD, Fisher SJ. Chemokine ligand and receptor expression in the pregnant uterus: reciprocal patterns in complementary cell subsets suggest functional roles. Am J Pathol 2001; 159:2199-2213. 
39. Red-Horse K, Drake PM, Fisher SJ. Human pregnancy: the role of chemokine networks at the fetal-maternal interface. Expert Rev Mol Med 2004; 6:1-14.

40. Cerri RLA, Thompson IM, Kim IH, Ealy AD, Hansen PJ, Staples CR, Li JL, Santos JEP, Thatcher WW. Effects of lactation and pregnancy on gene expression of endometrium of Holstein cows at day 17 of the estrous cycle or pregnancy. J Dairy Sci 2012; 95: 5657-5675.

41. Walker CG, Littlejohn MD, Mitchell MD, Roche JR, Meier S. Endometrial gene expression during early pregnancy differs between fertile and subfertile dairy cow strains. Physiol Genomics 2012; 44: 47-58.

42. Girardi G, Bulla R, Salmon JE, Tedesco F. The complement system in the pathophysiology of pregnancy. Mol Immunol 2006; 43:68-77.

43. Regal JF, Gilbert JS, Burwick RM. The complement system and adverse pregnancy outcomes. Mol Immunol 2015; 67:56-70.

44. Wen HY, Abbasi S, Kellems RE, Xia Y. mTOR: a placental growth signaling sensor. Placenta 2005; 26:S63-S69.

45. França MR, Mesquita FS, Lopes E, Pugliesi G, Van Hoeck V, Chiaratti MR, Membrive CB, Papa PC, Binelli M. Modulation of periovulatory endocrine profiles in beef cows: consequences for endometrial glucose transporters and uterine fluid glucose levels. Domest Anim Endocrinol 2015; 50:83-90.

46. Gao H, Wu G, Spencer TE, Johnson GA, Bazer FW. Select nutrients in the ovine uterine lumen. ii. Glucose transporters in the uterus and periimplantation conceptuses. Biol Reprod 2009; 80:94-104.

47. Baczyk D, Kingdom JC, Uhlén P. Calcium signaling in placenta. Cell Calcium 2011; 49:350-356.

48. Clapham DE. Calcium signaling. Cell 1995; 80:259-268.

49. Zoumakis E, Margioris AN, Stournaras C, Dermitzaki E, Angelakis E, Makrigiannakis A, Koumantakis E, Gravanis A. Corticotrophin-releasing hormone $(\mathrm{CRH})$ interacts with inflammatory prostaglandins and interleukins and affects the decidualization of human endometrial stroma. Mol Hum Reprod 2000; 6:344-351.

50. Makrigiannakis A, Margioris AN, Le Goascogne C, Zoumakis E, Nikas G, Stoumaras C, Psychoyos A, Gravanis A. Corticotropin-releasing hormone (CRH) is expressed at the implantation sites of early pregnant rat uterus. Life Sci 1995; 57:1869-1875.

51. Zimmerman TL, Thevananther S, Ghose R, Burns AR, Karpen SJ. Nuclear export of retinoid X receptor $\alpha$ in response to interleukin-1 $\beta$ mediated cell signaling: roles for JNK and SER260. J Biol Chem 2006; 281:15434-15440.
52. Song G, Fleming JA, Kim J, Spencer TE, Bazer FW. Pregnancy and interferon tau regulate DDX58 and PLSCR1 in the ovine uterus during the periimplantation period. Reproduction 2011; 141:127-138.

53. Green JC, Okamura CS, Poock SE, Lucy MC. Measurement of interferontau (IFN-tau) stimulated gene expression in blood leukocytes for pregnancy diagnosis within 18-20d after insemination in dairy cattle. Anim Reprod Sci 2010; 121:24-33.

54. Boruszewska D, Kowalczyk-Zieba I, Sinderewicz E, Grycmacher K, Staskiewicz J, Woclawek-Potocka I. The effect of lysophosphatidic acid together with interferon tau on the global transcriptomic profile in bovine endometrial cells. Theriogenology 2017; 92:111-120.

55. Groebner AE, Schulke K, Unterseer S, Reichenbach HD, Reichenbach M, Buttner M, Wolf E, Meyer HHD, Ulbrich SE. Enhanced proapoptotic gene expression of XAF1, CASP8 and TNFSF10 in the bovine endometrium during early pregnancy is not correlated with augmented apoptosis. Placenta 2010; 31:168-177.

56. Imakawa K, Imai M, Sakai A, Suzuki M, Nagaoka K, Sakai S, Lee SR, Chang KT, Echternkamp S, Christenson RK. Regulation of conceptus adhesion by endometrial CXC chemokines during the implantation period in sheep. Mol Reprod Dev 2006; 73:850-858.

57. Groebner AE, Schulke K, Schefold JC, Fusch G, Sinowatz F, Reichenbach $\mathrm{HD}$, Wolf E, Meyer HH, Ulbrich SE. Immunological mechanisms to establish embryo tolerance in early bovine pregnancy. Reprod Fertil Dev 2011; 23:619-632.

58. Riedmaier I, Spornraft M, Pfaffl MW. Identification of a potential gene expression biomarker signature in bovine liver to detect the abuse of growth promoters. Food Addit Contam Part A 2014; 31:641-649.

59. Han H, Austin KJ, Rempel LA, Hansen TR. Low blood Isg15 mRNA and progesterone levels are predictive of non-pregnant dairy cows. Endocrinology 2006; 191:505-512.

60. Shorten PR, Ledgard AM, Donnison M, Pfeffer PL, McDonald RM, Berg DK. A mathematical model of the interaction between bovine blastocyst developmental stage and progesterone-stimulated uterine factors on differential embryonic development observed on day 15 of gestation. J Dairy Sci 2018; 101:736-751.

61. Lussier JG, Diouf MN, Lévesque V, Sirois J, Ndiaye K. Gene expression profiling of upregulated mRNAs in granulosa cells of bovine ovulatory follicles following stimulation with hCG. Reprod Biol Endocrinol 2017; $15: 88$.

62. Akbarinejad V, Tajik P, Movahedin M, Youssefi R. The role of fibroblast growth factor receptor 2 (FGFR2) in differentiation of bovine spermatogonial stem cells (SCC). Vet Res Forum 2016; 7:149-153. 